\title{
Inmunopatología de la infección por virus SARS-CoV-2
}

\section{Immunopathology of SARS-CoV-2 virus infection}

\author{
Francisco Javier Espinosa-Rosales
}

\begin{abstract}
Resumen
Durante la pandemia por el virus SARS-CoV-2, que inició en 2019, se ha observado que la mayoría de individuos afectados tiene un cuadro clínico leve o es completamente asintomática. Sin embargo, alrededor de 15\% de los afectados tendrán una enfermedad grave y potencialmente fatal asociada con un síndrome de hiperinflamación, parecido al síndrome de activación macrofágica. Se ha documentado que las personas con cuadros clínicos leves tienen una respuesta inmune innata eficiente y una respuesta adaptativa, que elimina a las células infectadas por virus, dejando memoria inmunológica. Los cuadros graves se originan en individuos con estados proinflamatorios que tienen una respuesta inmunitaria innata tardía, un fenómeno de hiperinflamación y "tormenta de citocinas", inducido por el sistema inmune innato, que se asocia con defectos en la inmunidad adaptativa.

PALABRAS CLAVE: SARS-CoV-2; COVID-19; pandemia por virus; activación de macrófagos; respuesta inmunitaria innata; citocina; sistema inmunitario; inmunidad adaptativa.

Abstract

AFTER SARS-CoV-2 virus pandemic that started in 2019, it has been observed that the vast majority of people have a mild clinical picture or are completely asymptomatic. However, around $15 \%$ of affected people will have a severe, potentially fatal clinical course associated with hyperinflammation, similar to the macrophage activation syndromes. Individuals with mild clinical COVID-19 have an efficient innate immune response and an adaptive response that kills virus-infected cells leaving immune memory. Severe symptoms occur in individuals with proinflammatory stages who have a late innate immune response, hyperinflammation and "cytokine storm" phenomenon induced by the innate immune system and associated with defects in adaptive immunity. KEYWORDS; SARS-CoV-2; COVID-19; Virus Pandemic; Macrophage activation; Innate Immune Response; Cytokine; Immune System; Adaptative Immunity.
\end{abstract}

Centro de Inmunología, Alergia y Pediatría.

Hospital Ángeles, Lomas, Estado de México.

Recibido: 26 de mayo 2020

Aceptado: 1 de junio 2020

Correspondencia

Francisco Javier Espinosa-Rosales espinosa_francisco@yahoo.com.mx

Este artículo debe citarse como Espinosa-Rosales FJ. Inmunopatología de la infección por virus SARS-CoV-2. Acta Pediatr Méx 2020; 41 (Supl 1):S42-S50.

\section{INTRODUCCIÓN}

Una vez que el virus SARS-CoV-2 ingresa al epitelio respiratorio de una persona sana a través de gotículas esparcidas por un individuo enfermo al hablar, toser o estornudar, la dosis acumulada de inóculo viral y las condiciones generales del individuo, tienen impacto muy importante en cómo será el enfrentamiento con el sistema inmunitario del individuo.
Cuando el inóculo es pequeño y el individuo receptor es una persona joven con un sistema inmune sano, generalmente la batalla contra el virus se librará en las vías aéreas superiores y el sistema inmunitario innato. Éste está formado por los mecanismos de barrera del epitelio respiratorio, las inmunoglobulinas $\mathrm{G}(\operatorname{lgG})$ y A $(\lg \mathrm{A})$ naturales, la respuesta local de interferones tipo I, la activación de la cascada del complemento por vía alterna y la citotoxicidad mediada por células 
natural killer (NK); estas últimas serán suficientes para erradicar la infección, poca participación de la respuesta inmune adaptativa. Cuando el inóculo es grande, la respuesta inmunitaria innata no está en su mejor momento por enfermedades crónicas (diabetes, obesidad mórbida), o se trata de un individuo adulto mayor, donde existe senescencia del sistema inmune, el virus llegará con facilidad a las vías aéreas inferiores con el riesgo de causar una bronconeumonía y formas graves de COVID-19. ${ }^{1}$

\section{Respuesta inmune innata}

En general, la respuesta inmune innata se da in situ, en el tejido por donde entra el virus, en este caso el epitelio respiratorio. Posteriormente, las células del sistema inmune innato viajarán a los ganglios linfáticos regionales, o localizados dentro del mismo epitelio respiratorio, para montar una respuesta inmune adaptativa que involucra la participación de los linfocitos T cooperadores, linfocitos T citotóxicos, y linfocitos B productores de anticuerpos. Estas células pueden activarse y llevar a cabo sus funciones dentro de los ganglios linfáticos, pero conforme la infección se vuelve crónica o, en casos de daño muy severo, las células del sistema inmune adaptativo viajarán al tejido afectado para librar localmente la batalla contra el microorganismo agresor. ${ }^{2}$

El virus SARS-CoV-2 se une y penetra al epitelio respiratorio a través de la unión con un receptor en la superficie de la célula epitelial (enzima convertidora de angiotensina; ACE), que se expresa de forma más abundante en los adultos y, sobre todo, en varones; esto explica porqué este grupo de personas es el más afectado. Al unirse a su receptor, el virus penetra la célula y es sensado por los receptores PAMPS (por sus siglas en inglés de patrones moleculares asociados con patógenos). En este caso, principalmente por los receptores tipo toll (TLR por sus siglas en inglés) TLR3, TLR7 y TLR 8, que se activan después del contacto con el ARN viral. La vía de señalización de los TLR (Figura 1) induce en la célula infectada la producción de citocinas pro-inflamatorias, como el factor de necrosis tumoral alfa (TNF $\alpha$ ) y la interleucina-6 (IL-6) y, también, la producción de interferones de tipo inflamatorio o tipo I ( $\alpha$ y $\beta$ ). ${ }^{3,4}$

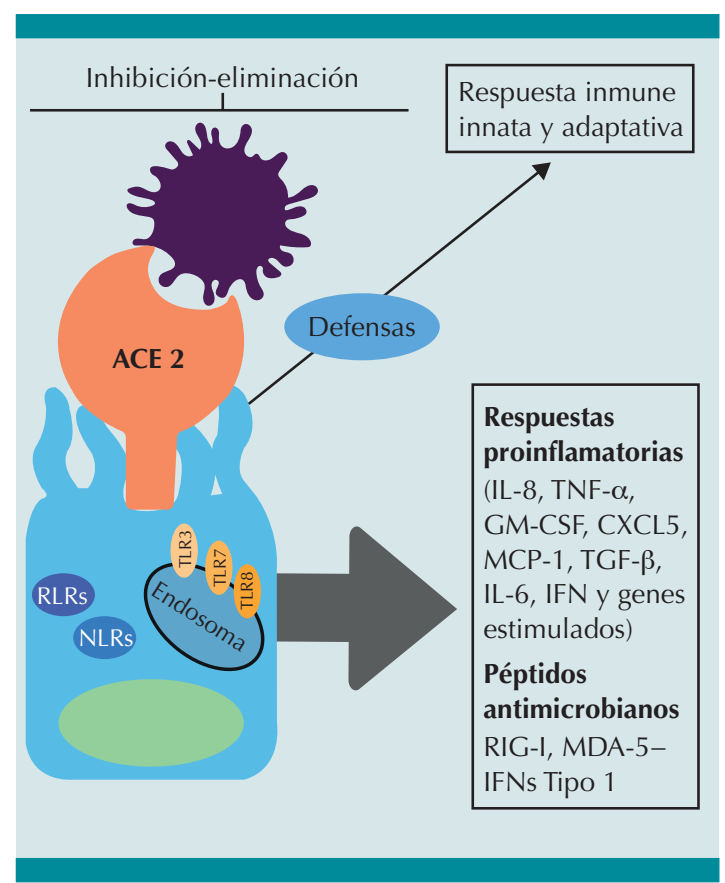

Figura 1. El virus SARS-CoV-2 se une al receptor ACE2 en el epitelio respiratorio y es "sensado" por los TLR 3, 7 y 8 que inician la señal de daño y, por consiguiente, una respuesta inflamatoria y de producción de interferón tipo I. (Modificada de Hallstrand TS, et al. Clin Immunol. 2014; 151: 1-15).

Las citocinas proinflamatorias inducen una señal de alarma en la células vecinas y activan el endotelio para atraer a células del sistema inmune adaptativo, que ayudarán en la lucha contra el organismo invasor. Los interferones tipo I (Figura 2) inhiben la síntesis de proteína viral, inducen la degradación del ARN del virus, inhiben la expresión de genes y el ensamble de viriones. 


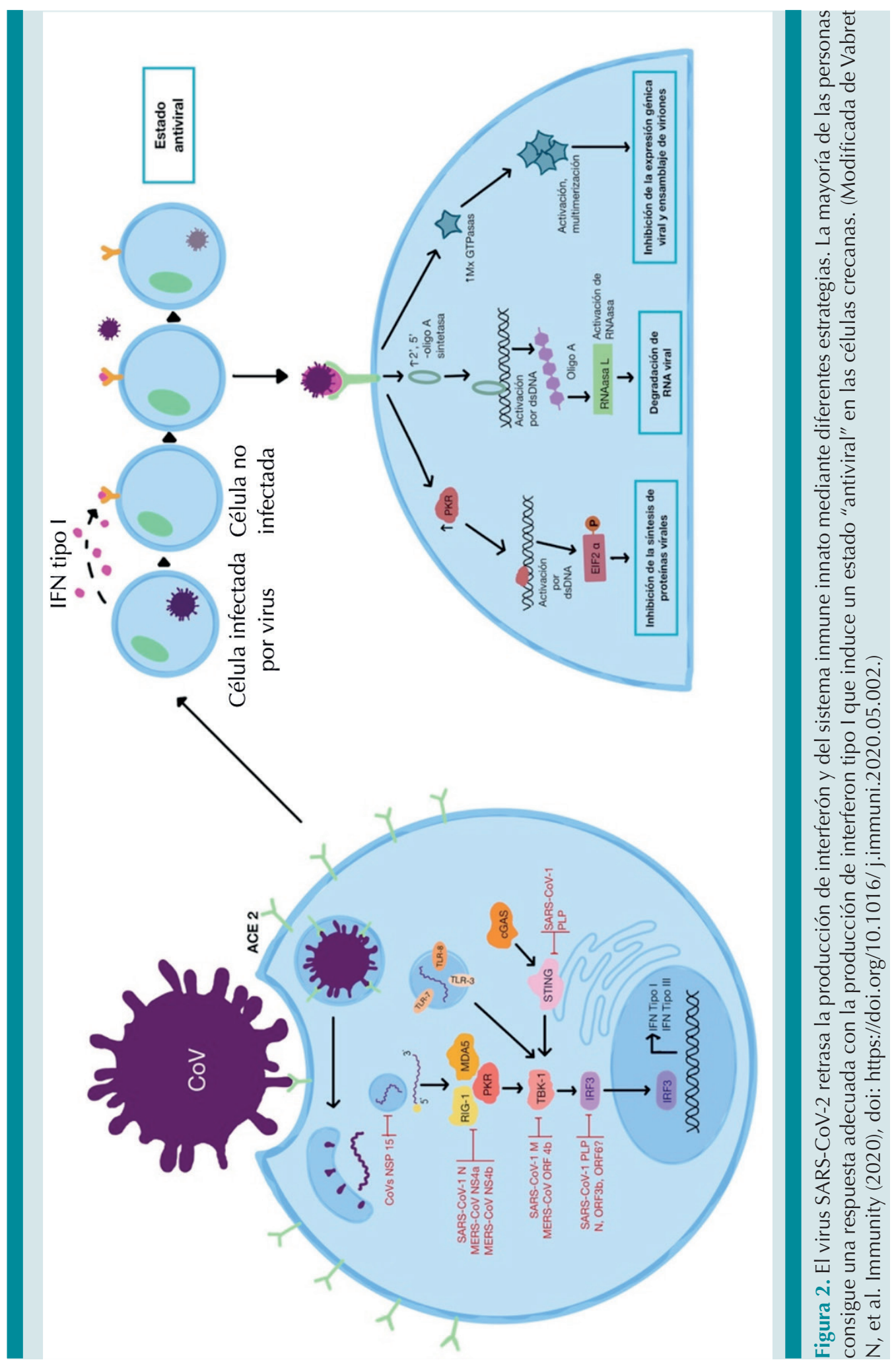


También inducen una disminución general del metabolismo celular que se traduce en un estado antiviral de las células vecinas..$^{3,4}$

El sistema de complemento puede activarse por la vía alterna, cuando el daño tisular es mayor y por activación mediada por complejos inmunitarios de y lgG con virus. La activación del complemento ayuda a opsonizar a las células infectadas por virus y permite una mejor citotoxicidad. La activación masiva del complemento se ha propuesto como una de las explicaciones más probables de la activación de trombina y los fenómenos trombóticos que se observan en pacientes con formas graves de COVID-19. ${ }^{1}$

La infección de la célula epitelial y la producción de interferón, citocinas proinflamatorias y quimiocinas, inducen cambios en la microcirculación local, activan el endotelio y facilitan la salida de células del sistema inmune como son células NK, monocitos, linfocitos y neutrófilos, activando a los macrófagos y células dendríticas residentes, que tendrán un perfil inflamatorio y contribuirán a la producción de más citocinas inflamatorias que pueden disparar una respuesta de hiperinflamación, responsable de las formas graves de la enfermedad. ${ }^{3}$

El sistema inmune innato y la forma en que se activa inicialmente, es el que determina el tipo de respuesta contra el virus SARS-CoV-2. Si la activación es moderada, inducirá una respuesta temprana y eficiente de interferon tipo I, se atraerá al sistema inmune adaptativo y habrá inflamación moderada que contribuirá a la erradicación de las células infectadas por virus y reparación posterior del daño.

Cuando la respuesta del interferón es tardía o insuficiente y el daño tisular causado por el virus es muy grande, o la respuesta inflamato- ria es desproporcionada, se genera una señal de daño muy grande que generará un estado hiperinflamatorio local, que generará una activación desproporcionada del sistema inmune adaptativo y el cuadro descrito de síndrome de activación macrofágica, similar a lo que se observa en una linfohistiocitosis hemofagocítica. ${ }^{5}$

\section{Respuesta inmune adaptativa}

Luego que el sistema inmune innato, en especial los macrófagos en el tejido afectado, fagocita las células muertas por la infección viral y se activan, expresando en su superficie marcadores de activación (moléculas del MHC-II, CD80, CD86), viajan por capilares linfáticos a los gaglios cercanos "buscando" linfocitos $\mathrm{T}$ cooperadores (LTh por sus siglas en inglés), cuyo receptor (TCR) reconozca péptidos del virus que están colocados en la superficie del MHC-II. Cuando estas dos células se encuentran, se lleva a cabo la sinapsis inmunológica, donde el macrófago u otra célula presentadora de antígenos profesional (linfocito B o célula dendrítica) activada, le "enseña" a los LTh, un péptido viral. Cuando los LTh reciben las señales adecuadas (reconocimiento de péptido y señales de coestimulación en el macrófago) se activan y empiezan a proliferar y a producir diferentes patrones de citocinas. Figura 3

Si en el microambiente donde se lleva a cabo esta "presentación de antígeno" existen muchas citocinas proinflamatorias (IL-1,6, TNF $\alpha$ ) e IL-12, el linfocito Th se diferencia como Th1 y produce grandes cantidades de IL-2 e interferón gamma $($ IFN- $\gamma$ ) que estimulan a los linfocitos NK y linfocitos CD8+ o LT citotóxicos (LTC) para llevar a cabo la citotoxicidad y muerte por apoptosis de las células infectadas por el virus. Los LTc viajan al sitio donde está la infección (vías aérea altas y bajas) y detectan células infectadas por virus que 


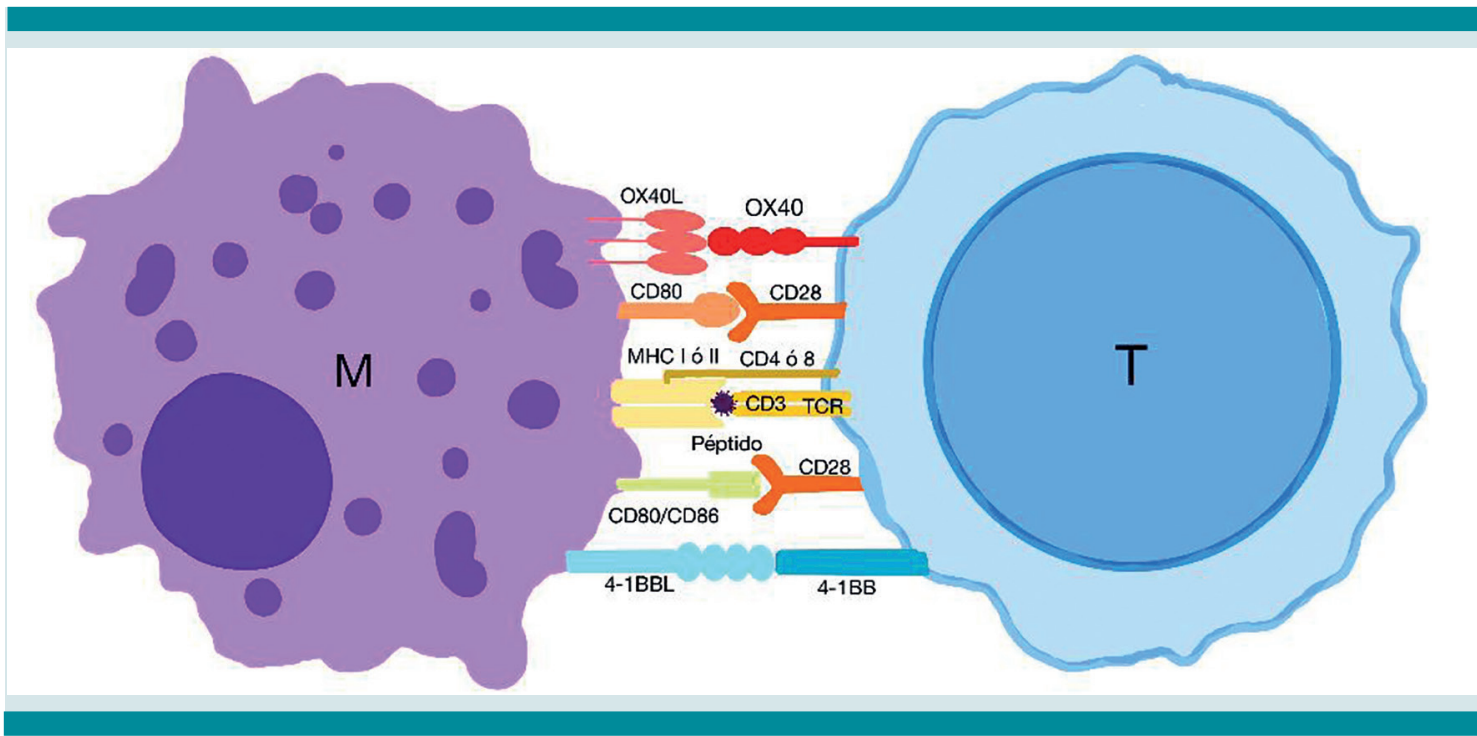

Figura 3. Sinapsis inmunológica. La interacción entre célula presentadora de antígeno profesional (macrófago) y el linfocito Th en un ganglio implica la presentación de un péptido derivado del coronavirus y reconocimiento por el TCR del LTh. El macrófago expresa marcadores de activación (MHC-II) y coestimulación (CD80, CD86, OX40L, 4-1BBL) que inducen la activación del LTh. M: macrófago, T: Linfocito Th.

expresan en su superficie MHC-I con péptidos del virus. Figura 4

Por lo general, al activarse la respuesta inmune en el ganglio, también existen en el microambiente citocinas (IL-4, -6, -10 y -13) que favorecen la diferenciación de algunos LTh hacia un perfil Th2. Los LTh2 producen más IL-4 y -10 que, en conjunto con el IFN- $\gamma$ de los LTh1, favorecen que los linfocitos B que reconozcan antígenos virales produzcan anticuerpos tipo IgG. Más adelante, en la mucosa respiratoria se producirá, predominantemente $\lg \mathrm{A}$, ya que allí predomina durante la activación de los linfocitos B, la IL-10 y el factor transformante de crecimiento beta (TGF- $\beta$, por sus siglas en inglés). Figura 5

Para resumir, la adecuada respuesta adaptativa incluye una buena respuesta Th1 y la inducción de citotoxicidad mediada por LTc y NK, así como una adecuada producción de anticuerpos IgM incialmente, que activan el complemento por la vía clásica, opsonizan células infectadas y producen complejos inmunitarios IgM-SARS-CoV-2 y más adelante IgG de memoria, que evitará la viremia y generará protección de largo plazo. También es importante la producción de IgA en mucosas que evite la adherencia del SARSCoV-2 a su receptor (ACE), en caso de volver a tener contacto con el virus en el futuro.

A pesar de que se ha visto una adecuada inducción de anticuerpos tipo IgG e IgA en los pacientes recuperados de COVID-19, en la actualidad se desconoce cuál será la duración y la eficacia de la protección a largo plazo.

\section{Síndrome de hiperinflamación asociado a COVID-19}

Desde que inició la pandemia de COVID-19 se ha identificado que, afortunadamente, la mayoría de los pacientes tiene una respuesta innata rápida y eficiente, que se coordina con 


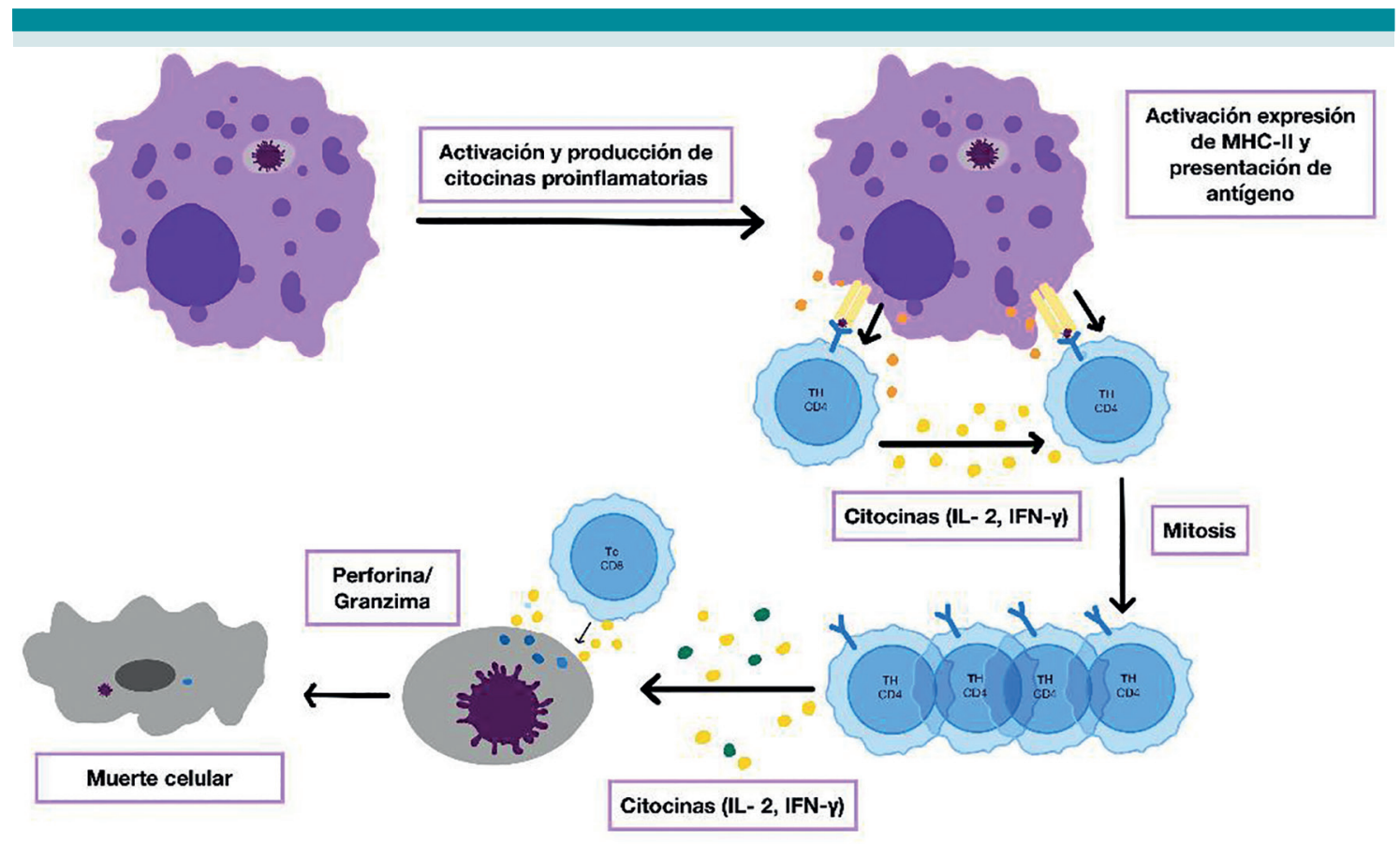

Figura 4. Un macrófago activado después de "sensar daño" en el epitelio respiratorio y haber fagocitado células que mueren por la infección por SARS-CoV-2 migra al ganglio linfático donde activa a un LTh que, a su vez, al activarse con perfil Th1 inducirá la producción de LT de memoria y grandes cantidades e IFN-g, que inducirá la citotoxicidad mediada por LTc y células NK que inducen la muerte por apoptosis de las células infectadas.

la respuesta adaptativa y genera inmunidad de memoria y un cuadro de infección, que va desde completamente asintomática hasta casos moderados parecidos a un cuadro de influenza, que desaparecen en 5 a 7 días. Alrededor de 12 a $15 \%$ de los pacientes con COVID-19 evoluciona a formas graves de la enfermedad.

La mayoría de individuos con formas graves de COVID-19 son varones mayores de 65 años que, por lo general, tienen comorbilidades: hipertensión, diabetes u obesidad entre otras. ${ }^{6}$ Es probable que varios mecanismos contribuyan a las formas graves, entre ellos: el envejecimiento afecta en numerosas formas al sistema inmune, disminuyendo el repertorio de linfocitos $\mathrm{T}$ y $\mathrm{B}$ y generando un estado proinflamatorio. ${ }^{7}$ Se cree que existe un mayor número de varones con formas graves por la mayor expresión del receptor viral (ACE) y mayor exposición ocupacional. Los pacientes con diabetes y obesidad también tienen una predisposición a reaccionar con inflamación exagerada. ${ }^{8}$

Se reportan, también, individuos jóvenes e, incluso, niños con formas graves de COVID-19. Se piensa que en estos individuos existe una predisposición genética, aún sin demostrar a la fecha de esta revisión.

\section{Los casos graves de COVID-19 son causados por un fenómeno de hiperinflamación desencadenada por el sistema inmune innato}

El perfil de producción sistémica de citocinas en las formas graves de COVID-19 se parece mucho al que se observa en los "sindromes de liberación 


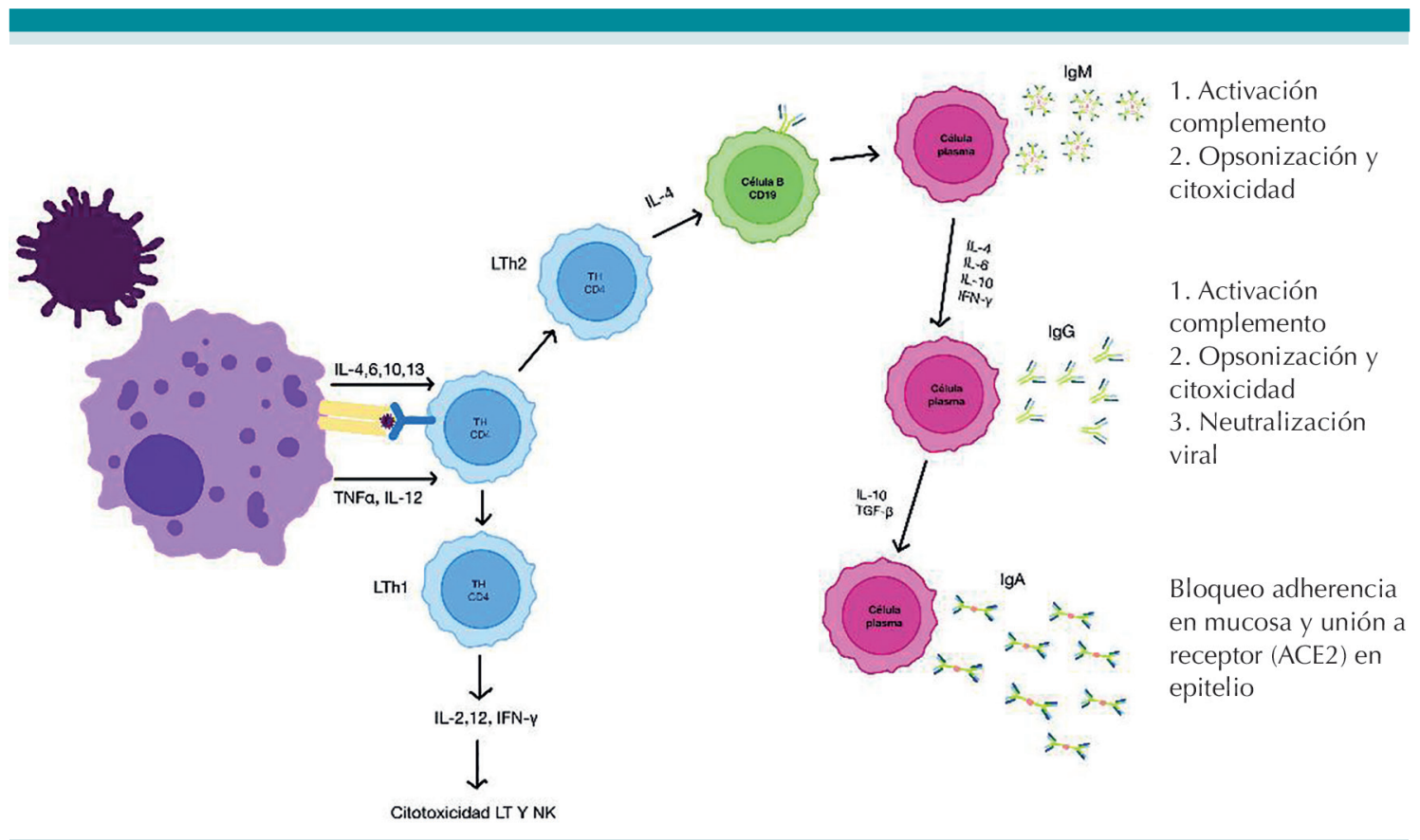

Figura 5. La respuesta inmunitaria de anticuerpos se da por la producción de IL-4, -6, -10, -13 que inducen a algunos LTh al activarse con perfil Th2 y que, junto con el IFN-g de los LTh1 inducirán al linfocito B a diferenciarse en una célula plasmática productora de IgM inicial y, posteriormente, IgG. En las mucosas, donde predomina la producción de TFG $\beta$, e IL-10 se induce, preferentemente, la producción de IgA secretora.

de citocinas", como el síndrome de activación macrofágica, con una producción muy elevada de citocinas como la IL-6, -7 y TNFa. También se secretan quimiocinas inflamatorias, como el ligando 2 de quimiocina CC (CCL2 por sus siglas en inglés), CCL3 y el ligando 10 de quimiocina CXC (CXCL10 por sus siglas en inglés). También se secretan grandes cantidades de la forma soluble de la cadena $\alpha$ del receptor de IL-2. Esto ha llevado a la hipótesis que son los monocitos o los macrófagos los principales culpables de la hiperinflamación.

Habitualmente, en el suero de pacientes con formas graves de COVID-19 se observan concentraciones muy elevadas de IL-6, pero no de IL-1. ${ }^{9}$

Un hallazgo común en las formas graves de COVID-19 es la linfopenia, que afecta a LT, LB y NK, pero es especialmente grave con LTc (CD8+).
Esta linfopenia puede deberse a un reclutamiento de LTc en el tejido afectado, a linfopoyesis alterada o secundaria al tratamiento con esteroides. Se ha observado una correlación inversa entre la concentración de citocinas proinflamatorias, como IL-6, y la cifra de linfocitos circulantes. ${ }^{10}$

Es probable que varios mecanismos contribuyan a la hiperactivación de los macrófagos, derivados de monocitos y la liberación masiva de citocinas, que se observa en pacientes con formas graves de COVID-19 (Figura 6). En primer término, una producción tardía de interferón tipo I, que conduce a mayor daño citopático por el virus y mayor activación de PAMPS, promueve la liberación mejorada de quimiocinas de monocitos por las células epiteliales alveolares (y quizá también por los macrófagos y células del estroma), lo que lleva 
Espinosa-Rosales FJ. Inmunopatología de la infección por virus SARS-CoV-2

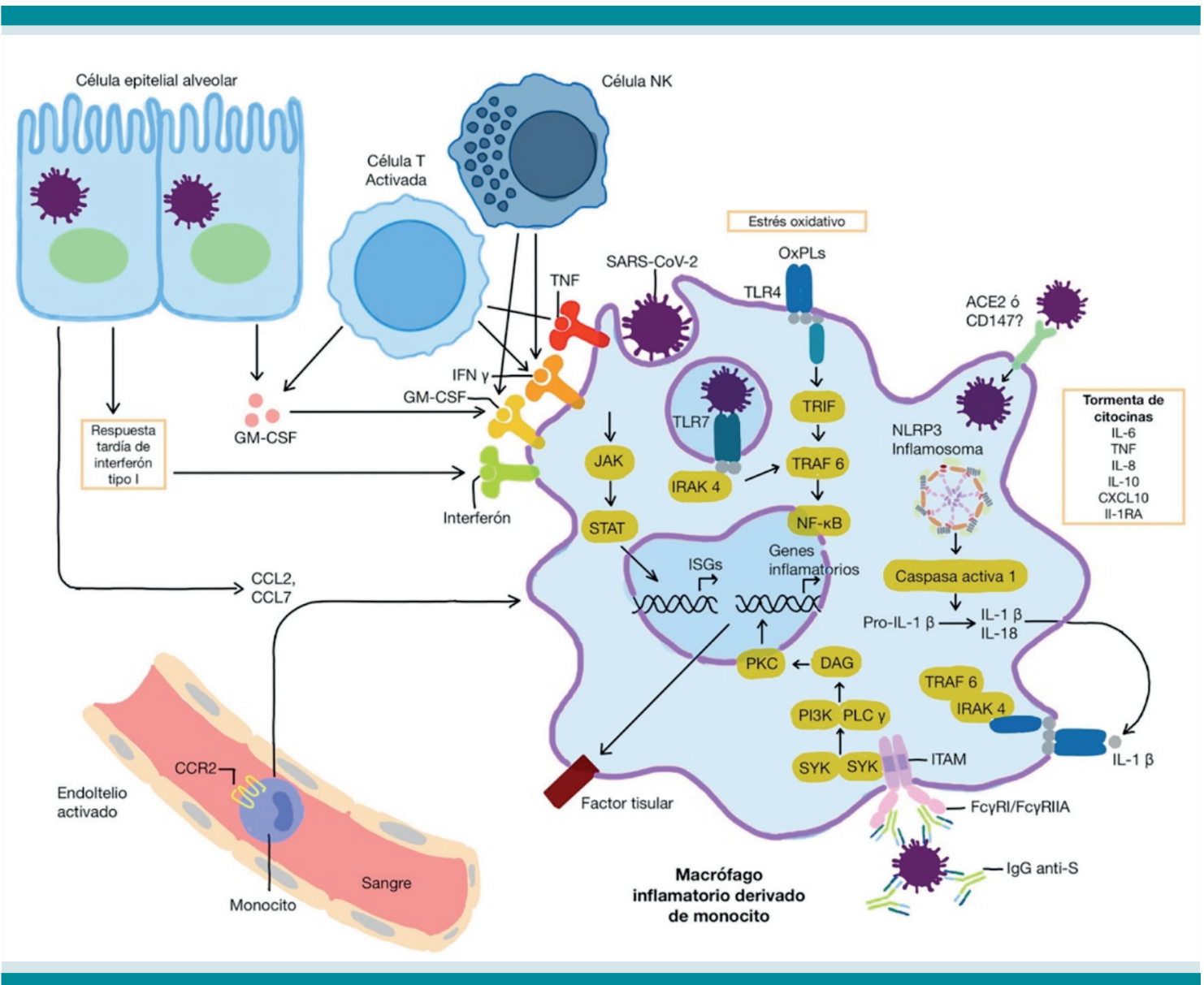

Figura 6. Mecanismos que contribuyen a la hiperactivación de los macrófagos derivados de monocitos y la liberación masiva de citocinas que se observa en pacientes con formas graves de COVID-19. (Modificado de Merad M, et al. Nat Rev Immunol (2020). https://doi.org/10.1038/s41577-020-0331-4).

a un reclutamiento prolongado de monocitos circulantes a los pulmones. Los monocitos se diferencian en macrófagos proinflamatorios a través de la activación de las vías de señalización de cinasa Janus (JAK por sus siglas en inglés) y el traductor de señales activador de la transcripción (STAT por sus siglas en inglés). Las células NK activadas y los LT promueven aún más el reclutamiento y la activación de macrófagos derivados de monocitos por la producción de factor estimulante de colonias de granulocitos-macrófagos (GM-CSF), TNF $\alpha$ e IFN $\gamma$. Los fosfolípidos oxidados (OxPL) se acumulan en los pulmones infectados y activan a los macrófagos a través de TLR4.

La detección de virus puede desencadenar la activación de TLR7 a través del reconocimiento de ARN viral. Es posible que los interferones tipo I induzcan la expresión de receptores de entrada del SARS-CoV-2, lo que permite que el virus acceda al citoplasma de los macrófagos y active el inflamasoma NLRP3 y secreción de IL-1 $\beta$ y / o IL-18.

La IL-1 $\beta$ puede amplificar la activación de macrófagos derivados de monocitos de forma 
autocrina o paracrina, pero también puede reducir la producción de interferón tipo I en los pulmones infectados. El daño de los receptores Fc $\gamma$ (FcyRs) por los complejos inmune de IgG anti-proteína $\mathrm{S}$ puede contribuir a la mayor activación inflamatoria de los macrófagos. ${ }^{9}$

\section{Agradecimientos}

El autor agradece la colaboración de María Espinosa Correa en la elaboración de las figuras que aparecen en este artículo.

\section{REFERENCIAS}

1. Matricardi PM, et al. The first, holistic immunological model of COVID-19: implications for prevention, diagnosis, and public health measures. Pediatr Allergy Immunol. Accepted Author Manuscript. doi:10.1111/pai.13271

2. Leo $\mathrm{O}$, et al. Vaccine Immunology. Perspectives in Vaccinology 2011; 1 : 25-59.
3. Vabret N, et al. The Sinai Immunology Review Project, Immunology of COVID-19: current state of the science. Immunity (2020) https://doi.org/10.1016/ j.immuni.2020.05.002.

4. Hallstrand TS, et al. Airway epithelial regulation of pulmonary immune homeostasis and inflammation. Clin Immunol. 2014; 151: 1-15. doi: 10.1016/j.clim.2013.12.003.

5. Santosha A, et al. The many faces of the anti-COVID immune response. J Exp Med. 2020; 217 (6): e20200678. https://doi. org/10.1084/jem.20200678

6. Richardson S, et al. Presenting characteristics, comorbidities, and outcomes among 5700 patients hospitalized with COVID-19 in the New York City Area. JAMA. April 22, 2020. doi:10.1001/jama.2020.6775

7. Pawelec G. Aging as an inflammatory disease and possible reversal strategies. J Allergy Clin Immunol. 2020; 145 (5): 1355-56. doi: 10.1016/j.jaci.2020.02.022.

8. Chait A, den Hartigh LJ. Adipose tissue distribution, inflammation and its metabolic consequences, including diabetes and cardiovascular disease. Front Cardiovasc Med. 2020; 7: 22. doi: 10.3389/fcvm.2020.00022. eCollection 2020.

9. Merad $\mathrm{M}$, et al. Pathological inflammation in patients with COVID-19: a key role for monocytes and macrophages. Nat Rev Immunol 2020. https://doi.org/10.1038/s41577-020-0331-4

10. Wang $F$, et al. Characteristics of peripheral lymphocyte subset alteration in COVID-19 pneumonia. J Infect Dis 2020; 221: 1762-69. https://doi.org/10.1093/infdis/jiaa150 